ISSN 1678-3921

Journal homepage: www.embrapa.br/pab

For manuscript submission and journal contents, access: www.scielo.br/pab
Felipe Amorim Caetano de Souza ${ }^{(1 \bowtie)}(0$, Tales Jesus Fernandes ${ }^{(1)}$, Fabiana Oliveira Cunha(1) Rafaela Aparecida Ribeiro(1) Fabiana Rezende Muniz(1) Sarah Laguna Conceição Meirelles ${ }^{(1)}$, Joel Augusto Muniz ${ }^{(1)}$ and Raquel Silva Moura ${ }^{(1)}$

(1) Universidade Federal de Lavras, Campus Universitário, Caixa Postal 3037, CEP 37200-000 Lavras, MG, Brazil. E-mail: felipeuflazootecnia@yahoo.com, talesest@yahoo.com.br, cunhazootecfabiana@gmail.com rribeiro17@outlook.com, fabiana.muniz@hotmail.com.br, sarah@ufla.br, joamuniz@ufla.br, raquelmourabr@yahoo.com.br

$\bowtie$ Corresponding author

Received

November 20, 2018

Accepted

August 8, 2019

How to cite

SOUZA, F.A.C. de; FERNANDES, T.J.; CUNHA, F.O.; RIBEIRO, R.A.; MUNIZ, F.R.; MEIRELLES, S.L.C.; MUNIZ, J.A.; MOURA, R.S. Morphometric characteristics of the Mangalarga Marchador horse breed determined by nonlinear models. Pesquisa Agropecuária Brasileira, v.54, e01145, 2019. DOI: https://doi. org/10.1590/S1678-3921.pab2019.v54.01145.

\section{Morphometric characteristics of the Mangalarga Marchador horse breed determined by nonlinear models}

\begin{abstract}
The objective of this work was to evaluate the development of the morphometric characteristics of Mangalarga Marchador horses through nonlinear models. The transversal method was used to collect data on height at the withers (HW), body length (BL), and thoracic (TP) and cannon (CP) perimeters from 200 horses ( 75 males and 125 non-pregnant females), aged between 6 and 153 months. The parameters of the Brody, Gompertz, logistic, and von Bertalanffy nonlinear models were estimated using the R software. Models were compared and selected using the coefficient of determination, the residual standard deviation, and the corrected Akaike information criterion. For adult females, HW, BL, TP, and CP ranged between 146.45-148.34, 148.59151.64 , 179.07-182.88, and 18.25-18.76 cm, respectively. For males, HW, BL, and CP ranged between 148.55-151.80, 150.77-154.88, and 18.95-19.41 cm, respectively. The logistic model best expresses growth in HW for males and females, as well as in BL and CP for males, whereas the Brody model is the best predictor for $\mathrm{HW}, \mathrm{BL}, \mathrm{TP}$, and $\mathrm{CP}$ for females. The increase in the values of the morphometric measurements is more rapid and homogeneous between the ages of 6 and 24 months, stabilizing at 60 months in both sexes.
\end{abstract}

Index terms: Equus caballus, Brody, Gompertz, logistic, modeling, von Bertalanffy.

\section{Características morfométricas de equinos da raça Mangalarga Marchador determinadas por modelos não lineares}

Resumo - O objetivo deste trabalho foi avaliar o desenvolvimento de características morfométricas de equinos Mangalarga Marchador por meio de modelos não lineares. Utilizou-se o método transversal para coletar dados de altura da cernelha (AC), comprimento corporal (CC) e perímetros torácico (PT) e de canela (PC) de 200 cavalos (75 machos e 125 fêmeas não gestantes), com idade entre 6 e 153 meses. Os parâmetros dos modelos não lineares de Brody, de Gompertz, logístico e de Von Bertalanffy foram estimados com uso do programa R. A comparação e a seleção dos modelos foi realizada por meio do coeficiente de determinação, do desvio-padrão residual e do critério de informação de Akaike corrigido. Nas fêmeas adultas, AC, CC, PT e PC variaram entre 146,45-148,34, 148,59-151,64, 179,07-182,88 e $18,25-18,76 \mathrm{~cm}$, respectivamente. Nos machos, AC, CC e PC variaram entre $148,55-151,80,150,77-154,88$ e 18,95-19,41 cm, respectivamente. O modelo logístico é o mais indicado para expressar o crescimento em $\mathrm{AC}$ em machos e fêmeas, bem como em CC e PC em machos, enquanto o de Brody é o melhor preditor de AC, CC, PT e PC em fêmeas. O aumento nos valores das medidas morfométricas é mais rápido e homogêneo entre as idades de 6 a 24 meses, e estabiliza-se aos 60 meses em ambos os sexos.

Termos para indexação: Equus caballus, Brody, Gompertz, logístico, modelagem, von Bertalanffy. 


\section{Introduction}

The Mangalarga Marchador horse breed, originated from southern Minas Gerais, Brazil, has been rising in popularity in recent years due to its characteristics, including comfort and docility, which are attractive for leisure and equestrian competitions (Fonseca et al., 2017). Since the breed's inception less than 200 years ago, its biotype has become more athletic, with higher quality morpho-functional features for a saddle horse (Casiuch, 2016). In this context, several studies have evaluated the growth characteristics of the horses of this breed (Souza et al., 2017; Ribeiro et al., 2018); however, few of them take into account morphometric variables, such as body length and thoracic and cannon perimeters, in statistical modeling.

Nonlinear models have been widely applied to assess the growth and development of several species. These models allow predicting animal growth and maturity, aiding in the management decision-making process, which helps to maximize animal production, considering the interpretation of the models' parameters (Freitas, 2005; Carneiro et al., 2014; Teleken et al., 2017).

In these models, animal growth is typically determined by morphometric measurements(Lawrence \& Fowler, 2002; Cabral et al., 2004; Santos et al., 2007; Rezende et al., 2016), including height at the withers, body length, and thoracic and cannon perimeters. These variables are usually studied because they reflect bone length and diameter, being related to the skeletal bone quality and the cardiorespiratory and workload capacity of horses during training exercises (Berbari Neto, 2009). Due to the relationship between animal morphology and locomotion, monitoring growth behavior over time through morphometric measures allows selecting suitable horses for equestrian sport competitions (Holmström \& Back, 2013; Staiger et al., 2016). Therefore, morphometric measurements can be used to select animals capable of superior performance.

In general, studies of horse growth involve repeated measurements of the same animal, frombirth to the adult phase (Santos et al., 2007; Garcia et al., 2011; Fradinho et al., 2016), known as the longitudinal method (Silva et al., 2010; Sperandio et al., 2011). However, acquiring data on the Mangalarga Marchador breed is difficult because most horses are sold by their owners before their growth stops at approximately five years of age. The transversal method is a practical and inexpensive alternative that allows collecting variables in a single event, shown to be very efficient in evaluating human (Zeferino et al., 2003) and horse (Souza et al., 2017; Ribeiro et al., 2018) growth.

Specifically for the Mangalarga Marchador breed, it is still necessary to evaluate if the pattern of morphometric characteristics is altered over time in males and females. This requires studies addressing new methodologies to assess horse growth.

The objective of this work was to evaluate the development of the morphometric characteristics of Mangalarga Marchador horses through nonlinear models.

\section{Materials and Methods}

Experimental data were obtained during an agricultural and livestock exhibition held at the municipality of Belo Horizonte, in the state of Minas Gerais, Brazil, in 2012. The study was approved by the animal research ethics committee of Universidade Federal de Lavras, under protocol number 039/12.

A total of 200 Mangalarga Marchador horses were evaluated: 75 males and 125 non-pregnant females, aged between 6 and 153 months. All animals were measured shortly after the sanitary inspection required for their entry in the exhibition center. The morphometric variables determined were: height at the withers, measured from the highest point of the interscapular region, located in the space defined by the T5 and T6 spinal processes, to the ground; body length, distance between the cranial portion of the major humerus tubercle and the caudal portion of the ischial tuberosity; thoracic perimeter, circumference measured just after the end of the withers, between the T8 and T9 spinal processes, passing through the intercostal space of the eighth and ninth vertebrae until the joint between the last rib and the xiphoid process; and cannon perimeter, circumference measured in the median region of the left shin, formed by the metacarpal bones II, III, and IV. A single examiner performed all measurements on the left side of the animal in stance position, i.e., four limbs supported and head in normal position, according to Cabral et al. (2004) and Santiago et al. (2016). The used tools included a height rod for measurement of height and length, and two 2-m measuring tapes, with 0.1 and $0.01 \mathrm{~cm}$ precision to measure the thoracic and cannon perimeters, respectively. 
The Brody, Gompertz, logistic, and von Bertalanffy nonlinear models were used to describe the morphofunctional variables for the growth curve of horses of both sexes, based on the following equations, respectively:

$$
\begin{aligned}
& \mathrm{y}_{\mathrm{i}}=\mathrm{a} \times\left\{1-\exp \left[\mathrm{b}-\mathrm{kt}_{\mathrm{i}}\right]\right\}+\varepsilon_{\mathrm{i}} \\
& \mathrm{y}_{\mathrm{i}}=\mathrm{a} \times \exp \left\{-\exp \left[\mathrm{b}-\mathrm{kt}_{\mathrm{i}}\right]\right\}+\varepsilon_{\mathrm{i}} \\
& \mathrm{y}_{\mathrm{i}}=\frac{\mathrm{a}}{\left\{1-\exp \left[\mathrm{b}-\mathrm{kt}_{\mathrm{i}}\right]\right\}}+\varepsilon_{\mathrm{i}} \\
& \mathrm{y}_{\mathrm{i}}=\mathrm{a} \times\left\{1-\exp \left[\mathrm{b}-\mathrm{kt}_{\mathrm{i}}\right]\right\}^{3}+\varepsilon_{\mathrm{i}}
\end{aligned}
$$

For all equations, $\mathrm{y}_{\mathrm{i}}$ is the studied animal variable; $\mathrm{a}$ is the asymptotic value or height, length, and adult perimeter of the animal; $b$ is the location parameter associated with the inflection point of the model, i.e., the age at which the animal shifts from accelerated to decelerated growth, until stabilizing at the maximum value $\mathrm{a} ; \mathrm{k}$ is the animal's growth rate or precocity index - the higher its value, the less time will be required for the animal to reach, for example, adult height; $t_{i}$ is the age at which the animal was measured; and $\varepsilon_{\mathrm{i}}$ is the experimental error associated with the measurement of variable $\mathrm{i}$ and that is assumed to be random, independent, and with normal distribution $\mathrm{N}\left(0, \sigma^{2}\right)$.

The nonlinear model parameters were estimated by the least-squares method, which was applied to obtain the system of normal equations. For this, the Gauss-Newton numerical algorithm was used in the $\mathrm{R}$ software ( $\mathrm{R}$ Core Team, 2015), estimating these parameters with the gnls( ) and $\operatorname{lm}$ () functions that fit the nonlinear models by the generalized least-squares method in the nlme package. For the comparison and selection of the most appropriate model, three fit quality assessors were used. The first was the residual standard deviation (RSD), calculated as $\mathrm{RSD}=\sqrt{\mathrm{RMS}}$, where RMS is the residual mean square; lower RSD values indicate a better fit. The second was the coefficient of determination $\left(\mathrm{R}^{2}\right)$, calculated as $\mathrm{R}^{2}=$ 1 - RSS/SSTotal, where RSS is the residual square sum and SSTotal is the total sum of squares; the $\mathrm{R}^{2}$ varies between 0 and 1, and higher values indicate a better fit. The third was the corrected Akaike information criterion $\left(\mathrm{AIC}_{\mathrm{c}}\right)$, calculated by: $\mathrm{AIC}_{\mathrm{c}}=\ln (\mathrm{RMS} / \mathrm{n})+2$ $(\mathrm{q}+1)+\{[2(\mathrm{q}+1)(\mathrm{q}+2)] / \mathrm{n}-(\mathrm{q}+2)\}$, where $\mathrm{n}$ is the sample size and $\mathrm{q}$ is the number of model parameters; lower $\mathrm{AIC}_{\mathrm{c}}$ values correspond to a better fit.
The Shapiro-Wilk test, at $1 \%$ probability, was applied to evaluate data normality, except for the thoracic perimeter of male horses (Table 1). Assuming residue normality, the confidence intervals for the parameter estimates were also obtained. The $95 \%$ confidence interval (CI) for parameter $\beta \mathrm{i}$ of a given model is defined as $\mathrm{CI}(\beta \mathrm{i})$ : bi $\pm \mathrm{t}(\mathrm{v} ; 0 ; 0.25) \times \mathrm{S}(\mathrm{bi})$, where bi is the estimate for parameter $(\beta \mathrm{i}) ; \mathrm{S}(\mathrm{bi})$ is the standard error of the estimate; and $t(v ; 0 ; 0.25)$ is the upper quantile of Student's t-distribution, considering $\alpha=$ $5 \%$ and the degree of freedom $\mathrm{v}=\mathrm{n}-\mathrm{p}$. All statistical tests, as well as all their computational analyses, were performed using the R software (R Core Team, 2015).

\section{Results and Discussion}

For height at the withers, the model fit quality indicators were efficient in describing the horse growth curve, with $\mathrm{R}^{2}$ varying from 85.6 to $87.8 \%$. For both males and females, the logistic model was the most efficient growth descriptor, with higher $\mathrm{R}^{2}$ and lower $\mathrm{RSD}$ and $\mathrm{AIC}_{\mathrm{c}}$ values. McManus et al. (2010) found $R^{2}$ values ranging from 0.12 to 0.66 for height at the withers of the Hanoverian, Brazilian Sport Horse, and Thoroughbred breeds, as well as of the crossbred horses reared by the Brazilian army, whereas Fradinho et al. (2016) obtained $\mathrm{R}^{2}$ values from 0.94 to 0.95 for Lusitano horses. These differences in the fit quality of the models may be related to the breed biotypes: although all horses are saddled, the Mangalarga Marchador breed was developed for work, while the other ones were developed for sport. Another explanation for these differences is the use of the transversal method for data collection in the present study, since the quality of the obtained fit may be related to the independence of errors due to nonrepeated measurements in the same animal (Carneiro et al., 2014); this shows the efficiency of the method and that it can be used to describe the growth of the Mangalarga Marchador breed.

It should be noted that, in the present study, Weibull's and Richards' models were not used because the parameter estimation algorithms did not converge for any of the morphometric variables; this may be attributed to the fact that the used growth data does not take into account animals with less than six months of age, a period with higher growth intensity. The segmented quadratic response plateau model was also tested but not used, due to the even worse quality 
of fit results. However, Fradinho et al. (2016) found that Richards' model is the most reliable to analyze the growth of 121 Lusitano foals, besides being the one that most closely described the breed pattern. Likewise, Santos et al. (2007) also concluded that this was the most efficient model for Pantanal horses. These findings show that it is necessary to study rigorously horse growth as the data from descriptive models may vary according to the different genetic groups within a given species.
The height at the withers obtained by the models ranged from 146.45 to $148.34 \mathrm{~cm}$ for females and from 148.55 to $151.80 \mathrm{~cm}$ for males (Table 2). These results were found to be consistent with the Mangalarga Marchador breed pattern, whose height at the withers should fall between $140-154$ and $147-157 \mathrm{~cm}$ for females and males, respectively; the ideal height is $146 \mathrm{~cm}$ for females and $152 \mathrm{~cm}$ for males (ABCCMM, 2000). Cabral et al. (2004) reported height at the withers of $151.5 \mathrm{~cm}$ for males and $151.6 \mathrm{~cm}$ for females, which

Table 1. P-value of the Shapiro-Wilk test (SW), coefficient of determination $\left(\mathrm{R}^{2}\right)$, residual standard deviation (RSD), and corrected Akaike information criterion $\left(\mathrm{AIC}_{\mathrm{c}}\right)$ in the fit adjustment evaluation of the morphometric measurements for the growth models for male and female Mangalarga Marchador horses, aged between 6 and 153 months.

\begin{tabular}{|c|c|c|c|c|c|c|}
\hline $\begin{array}{c}\text { Morphometric } \\
\text { measurement }(\mathrm{cm})\end{array}$ & Model & Sex & SW & $\mathrm{R}^{2}$ & RSD & $\mathrm{AIC}_{\mathrm{c}}$ \\
\hline \multirow{8}{*}{ Height at the withers } & Brody & Male & 0.2896 & 0.8738 & 3.066 & 218.19 \\
\hline & & Female & 0.4654 & 0.8562 & 2.726 & 319.75 \\
\hline & Gompertz & Male & 0.3102 & 0.8761 & 3.043 & 217.57 \\
\hline & & Female & 0.4601 & 0.8570 & 2.720 & 319.46 \\
\hline & Logistic & Male & 0.3382 & 0.8782 & 3.023 & 217.00 \\
\hline & & Female & 0.4405 & 0.8576 & 2.710 & 319.23 \\
\hline & von Bertalanffy & Male & 0.3010 & 0.8754 & 3.050 & 217.77 \\
\hline & & Female & 0.4619 & 0.8567 & 2.722 & 319.55 \\
\hline \multirow{7}{*}{ Body length } & Brody & Male & 0.3912 & 0.9122 & 3.478 & 228.79 \\
\hline & & Female & 0.0140 & 0.7869 & 4.724 & 391.24 \\
\hline & Gompertz & Male & 0.4323 & 0.9129 & 3.467 & 228.51 \\
\hline & & Female & 0.0118 & 0.7844 & 4.742 & 391.74 \\
\hline & Logistic & Male & 0.4831 & 0.9133 & 3.459 & 228.33 \\
\hline & & Female & 0.0104 & 0.7818 & 4.761 & 392.26 \\
\hline & von Bertalanffy & Male & 0.4133 & 0.9127 & 3.470 & 228.59 \\
\hline \multirow{8}{*}{ Thoracic perimeter } & & Female & 0.0125 & 0.7852 & 4.730 & 391.57 \\
\hline & Brody & Male & 0.0096 & 0.8995 & 4.222 & 245.06 \\
\hline & & Female & 0.7765 & 0.8623 & 5.007 & 398.79 \\
\hline & Gompertz & Male & 0.0073 & 0.8991 & 4.229 & 245.21 \\
\hline & & Female & 0.7462 & 0.8595 & 5.045 & 399.79 \\
\hline & Logistic & Male & 0.0064 & 0.8984 & 4.240 & 245.42 \\
\hline & & Female & 0.7205 & 0.8567 & 5.083 & 400.76 \\
\hline & von Bertalanffy & Male & 0.0078 & 0.8992 & 4.226 & 245.15 \\
\hline \multirow{8}{*}{ Cannon perimeter } & Brody & Male & 0.6020 & 0.8605 & 0.448 & 56.63 \\
\hline & & Female & 0.0386 & 0.7650 & 0.523 & 105.04 \\
\hline & Gompertz & Male & 0.5279 & 0.8621 & 0.446 & 56.24 \\
\hline & & Female & 0.0339 & 0.7617 & 0.525 & 105.65 \\
\hline & Logistic & Male & 0.4591 & 0.8636 & 0.444 & 55.88 \\
\hline & & Female & 0.0298 & 0.7585 & 0.528 & 106.23 \\
\hline & von Bertalanffy & Male & 0.5521 & 0.8616 & 0.447 & 56.37 \\
\hline & & Female & 0.0355 & 0.7628 & 0.524 & 105.45 \\
\hline
\end{tabular}




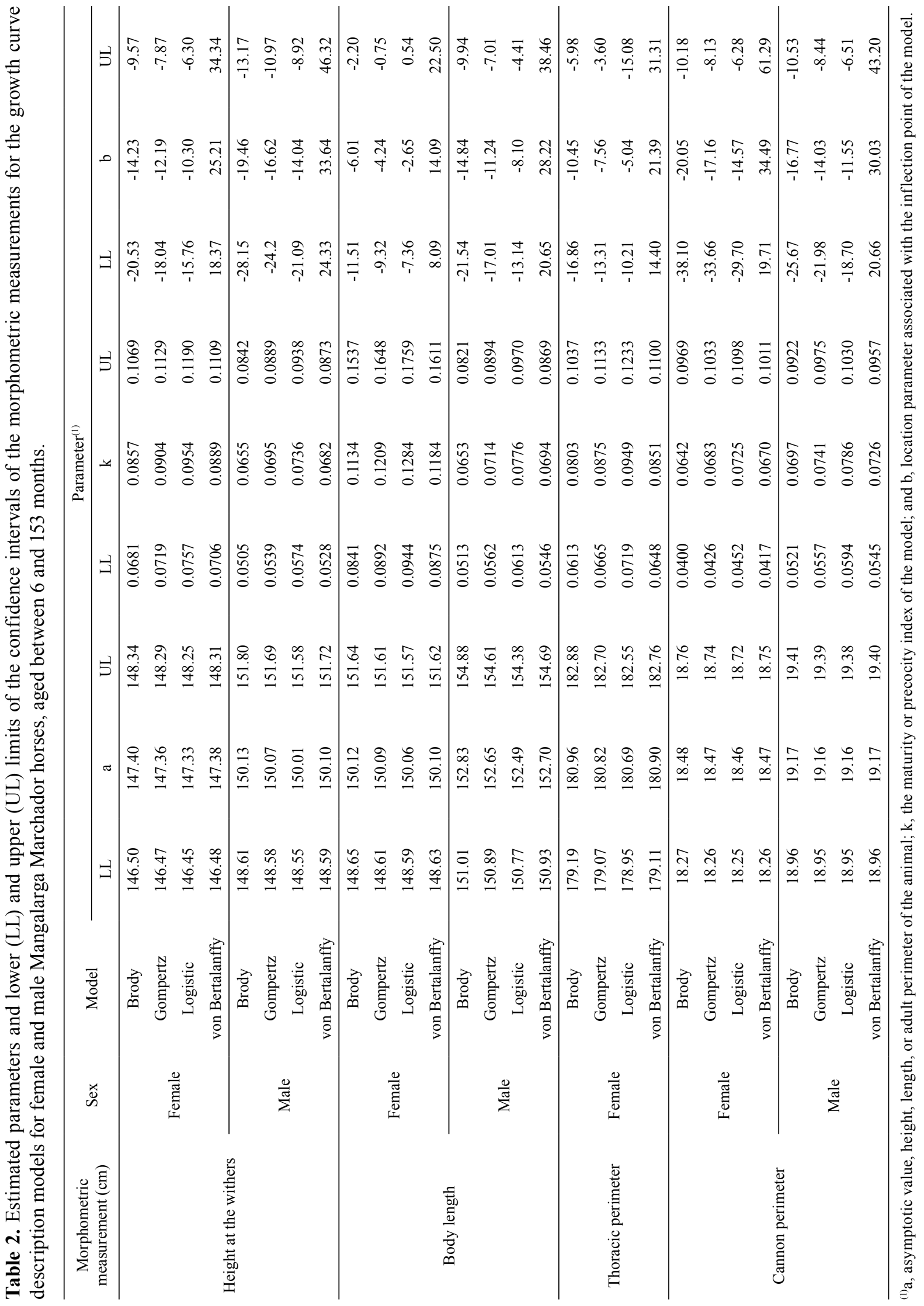


were slightly larger. Santiago et al. (2016) compared the mean height at the withers of the Mangalarga Marchador national champions with that of the current herd, obtaining average values close to those of the present study: 151 and $150 \mathrm{~cm}$ for champion and current herd males, respectively, and 150 and $146 \mathrm{~cm}$ for champion and current herd females.

When comparing males and females, growth differences became evident. The models' "a" parameter fits and the lower and upper confidence intervals for height at the withers are indicative that males are larger than females (Table 2), as the greatest height of females $(148.34 \mathrm{~cm})$ was lower than the lowest height of males $(148.55 \mathrm{~cm})$; furthermore, as these values did not overlap, they differed statistically. Mota et al. (2010) also concluded that males are generally taller than females. These differences between both sexes can be explained by sexual dimorphism: in males, secondary sexual characteristics influence the growth of tissues and, consequently, of body regions, which leads to differences in growth patterns related to height (Pimentel et al., 2017).

Females were more precocious than males in terms of height at the withers, with a higher estimated k-value (Table 2). This precocity may also be related to sexual dimorphism characteristics: despite being smaller than males, females reach adulthood sooner. Other factors may also have influenced the differences in the development of both sexes, including handling conditions, which often vary between animals. In the Mangalarga Marchador breed, there is a tendency to feed male and female horses different diets, particularly in the animals' early years, when nutritional requirements are greater due to increased body growth. Females have a higher market value because they are directed to the production of future matrices and serve as embryo donors of the breeding farms; therefore, they generally receive food with improved nutritional quality, besides adequate supplements and sanitary management. Males have a lower added value and are directed towards sale; only those exhibiting greater zootechnical superiority for breeding are kept at the farms. As a result, males often receive inferior care, yielding a comparatively slower growth. McManus et al. (2010) found few differences in the maturation rate of both male and female horses bred by the Brazilian army, suggesting that the precocity of males and females depends on the breed. However, it is worth noting that the herd of army animals is not commercial, which means there is no market pressure, allowing a similar rearing of males and females.

Regarding body length, the statistical models were efficient in describing the horse growth curve, with $\mathrm{R}^{2}$ ranging from 78.2 to $91.3 \%$. The best predictors for this parameter in males and females were the logistic and Brody models, with which lower RSD and $\mathrm{AIC}_{\mathrm{c}}$ values were also found (Table 1). The body lengths obtained by the models ranged from 148.59 to 151.64 $\mathrm{cm}$ for females and from 150.77 to $154.88 \mathrm{~cm}$ for males (Table 2). However, Cabral et al. (2004), while studying animals of the same genetic group, reported values of 157.6 and $149.4 \mathrm{~cm}$ for males and females, respectively. It should be highlighted that males are always longer than females, which may also be related to sexual dimorphism, as stated by Miserani et al. (2002). These authors observed that growth, besides being influenced by sex, is affected by the environmental conditions specific to the animals' breeding region and year of birth. The horses in the present study originated from different regions of the country, with variations in edaphoclimatic and management conditions; this may have caused the differences between individuals and between both sexes.

Females were more precocious in body length than males (Table 2), which may be attributed not only to sex, but also to the different husbandry conditions to which these animals were subjected throughout their productive lives. As previously mentioned, males are used for sale at auctions and fairs, serving as a source of income for breeders, being handled differently than females. These differences in handling may be an indicative of the stress to which the animals are exposed at the time of weaning. As reported by Gonçalves et al. (2012), poor nutritional conditions at weaning cause worse gains in morphometric characteristics; these restrictions slow down the initial growth rates, which should be high at the beginning of life, leading to differences in precocity, as verified in the present study.

The thoracic perimeter for Mangalarga Marchador males did not follow a normal distribution, making it impossible to apply the nonlinear models to this dataset (Table 1). However, when only female thoracic perimeter data were analyzed, the fit quality indicators showed that the statistical models were efficient in predicting this parameter, with $\mathrm{R}^{2}$ ranging from 85.6 to $86.2 \%$; the Brody model had the best fit, with the highest $\mathrm{R}^{2}$ and lowest $\mathrm{RSD}$ and $\mathrm{AIC}_{\mathrm{c}}$ values 
(Table 2). Fradinho et al. (2016) found $\mathrm{R}^{2}$ values of 95\% for females, when evaluating the Brody, logistic, Gompertz, von Bertalanffy, and Richards models. In the present study, the thoracic perimeters obtained by the different models ranged from 179.07 to 182.88 $\mathrm{cm}$ for females (Table 2). Cabral et al. (2004) reported lower thoracic perimeters of $175.7 \mathrm{~cm}$ for females of the same breed.

The analysis of cannon perimeter showed that the statistical models were efficient predictors of this parameter, with $\mathrm{R}^{2}$ ranging from 75.85 to $86.3 \%$; the Brody and the logistic models fitted female and male relative data best, respectively, with the highest $\mathrm{R}^{2}$ and lowest RSD and $\mathrm{AIC}_{\mathrm{c}}$ values (Table 1). Contrary to these results, Fradinho et al. (2016) found the Richards model to be the best predictor of cannon perimeter in the Lusitano breed. The cannon perimeters obtained by the models ranged from 18.25 to $18.76 \mathrm{~cm}$ for Mangalarga Marchador females and from 18.95 to $19.41 \mathrm{~cm}$ for males (Table 2). These results are indicative that bone growth behavior differs between sexes. Like height at the withers and body length, the shin perimeter of males tends to be larger than that of females, which gives them an advantage in daily training by breeders, leading to an increase in the load capacity of their body parts for work and also in their productive life. The observed differences may also be due to sexual dimorphism, as females usually present more well-defined and thinner bone spokes and contours than males.

Unlike the observed for the other morphometric measures, males are more precocious than females in terms of cannon perimeters (Table 2). This indicates that bone tissue growth may differ between both sexes, since males, which are larger and heavier, need thicker bones to support their entire body. In addition, growth in height and length is more accelerated in females, causing the bones that form the body diameters to grow slowly. However, further studies are needed to confirm this hypothesis in this horse breed.

All studied morphometric variables showed a similar growth behavior with age (Figure 1). Growth was more intense and homogeneous for Mangalarga Marchador animals aged from 6 to 24 months, in alignment with the pattern observed for the Arabian horse (Reed \& Dunn, 1977). Mota et al. (2010), analyzing foals of the Quarto de Milha breed, described a greater uniformity in growth regarding height at the withers and thoracic perimeter in animals up to 19 months of age. Santos et al. (2007) found that the variation in growth was greater in the early months, but decreased with age; this may be related to hyperplasia and muscle hypertrophy. In the Mangalarga Marchador breed, the allometric growth of different body tissues, such as bone and muscle, which tends to be greater in the first years of life of the horse, may also lead to different body growth patterns.

From 24 months of age onwards, a greater variability was observed in the morphometric variables. These variations may be attributed to possible changes in the nutritional and health management systems, training methodologies, and genetic factors (Santos et al., 2007), as well as to individual differences, since the Mangalarga Marchador breed has undergone less than 200 years of selection compared with other breeds such as Thoroughbred and Arabian (Casiuch, 2016).

Some postnatal variations in animal growth over time, especially after 24 months of age, may stem from changes in the prenatal stage. In Mangalarga Marchador breeding, for example, a common practice is to transfer embryos from the best mares of the breed to surrogates, which often do not receive quality management, particularly in terms of their nutrition. Due to the lack of knowledge of animal growth, most breeders and professionals do not take into account how alterations in the care of the mother may affect the uterine environment and, therefore, fetal gene expression. These changes lead to physiological growth deficiencies, such as decreased muscle hyperplasia, which occur in the fetal phase, besides causing irreversible damage during the lifetime of the horses (Lawrence \& Fowler, 2002). The postnatal growth of foals may also be linked to mare size, which is related to uterine size and, consequently, to the amount of placenta, which is responsible for providing nutrients to the fetus (Allen et al., 2002; Peugnet et al., 2015). In the Mangalarga Marchador breed, therefore, the use of small-sized surrogates chosen without prior selection may influence the postnatal growth of animals.

At approximately 60 months of age, the growth curves of all morphometric variables stabilized for both sexes (Figure 1). This suggests that the studied Mangalarga Marchador animals grow in height, length, and perimeters up to this age. Therefore, the best period to evaluate and obtain the morphometric measurements of the breed is from the age of five onwards, when horses cease growing and the variability of these measures decreases, reducing 

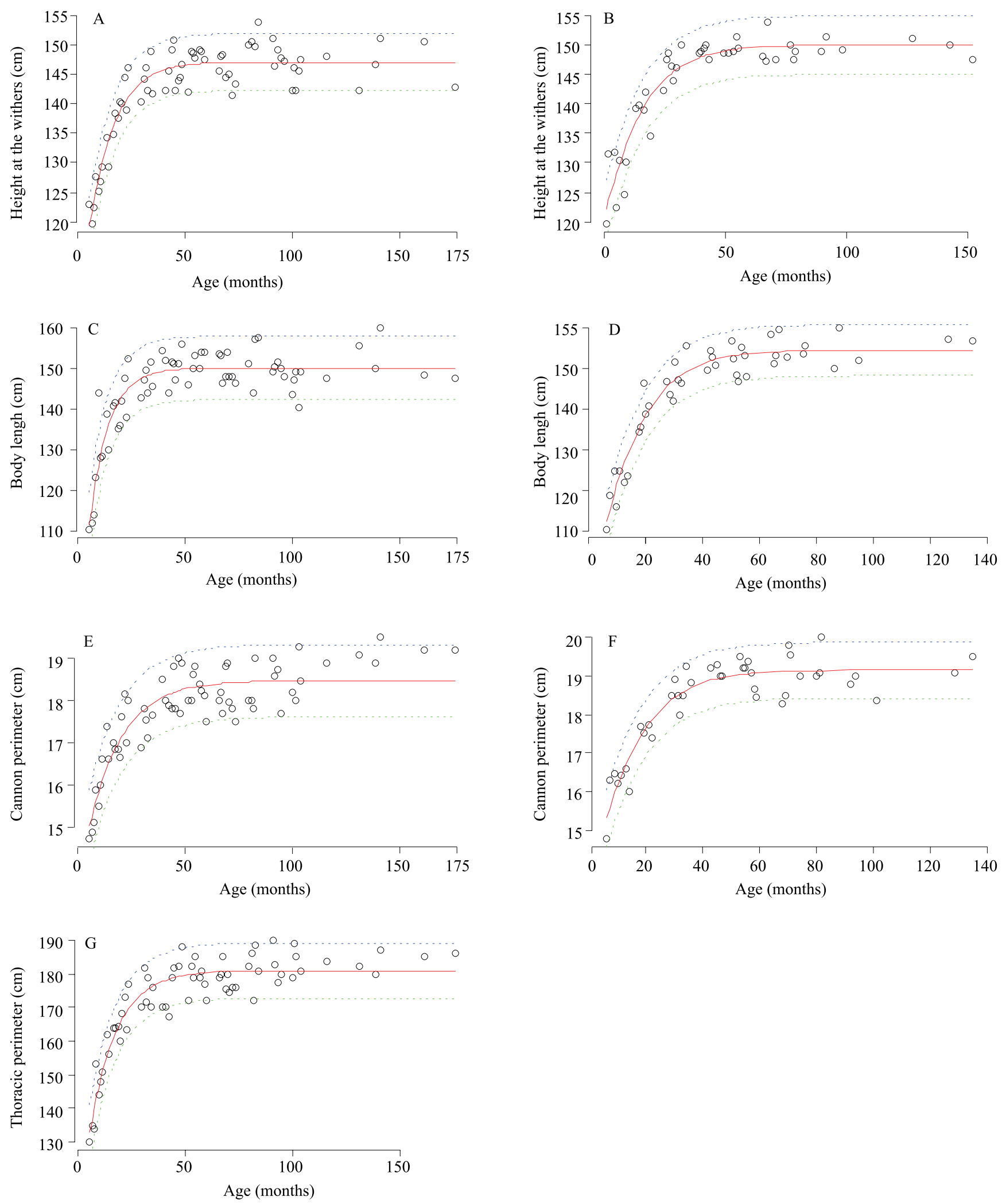

Figure 1. Growth curve, with respective confidence intervals, for height at the withers for females (A) and males (B), body length for females (C) and males (D), cannon perimeter for females (E) and males (F), and thoracic perimeter for females (G) of the Mangalarga Marchador horse breed, aged between 6 and 153 months. 
measurement errors. Reed \& Dunn (1977) observed that Arabian male horses also grow in height up to 60 months. However, these results differ from those of Miserani et al. (2002), who stated that the best time to measure and evaluate morphometry in Pantanal horses is from four years of age onwards. Therefore, even if the growth of a breed or species is genetically determined (Lawrence \& Fowler, 2002), actual growth also depends on environmental factors, which, together with genetic factors, will yield different growth patterns (Mota et al., 2010).

Knowledge of the morphometric measurements related to growth in Mangalarga Marchador horses enables the correct selection of animals in advance. Moreover, it provides breeding centers with adequate tools to decide on the most effective nutritional and sanitary managements, avoiding economic losses and unnecessary expenses to restore normal development throughout the animals' productive life.

\section{Conclusions}

1. The transversal data collection method may be applied to study the grow th curves for the morphometric measurements of Mangalarga Marchador horses aged between 6 and 153 months, using the Brody, Gompertz, logistic, and von Bertalanffy nonlinear models.

2. The increase in the values of morphometric measurements is more rapid and homogeneous between the ages of 6 and 24 months, stabilizing at 60 months in both sexes.

3. The logistic model best expresses growth in height at the withers for males and females, as well as body length and cannon perimeter for males, whereas the Brody model is the best predictor for body length, thoracic perimeter, and cannon perimeter for females.

4. Females show greater precocity than males in reaching adult height, length, and thoracic perimeter.

\section{Acknowledgments}

To Programa de Pós-Graduação em Zootecnia and to Núcleo de Estudos em Equideocultura of Universidade Federal de Lavras (UFLA), to Fundação de Amparo à Pesquisa doEstadodeMinas Gerais(Fapemig), toConselho Nacional de Desenvolvimento Científico e Tecnológico (CNPq), to Coordenação de Aperfeiçoamento de Pessoal de Nível Superior (Capes), and to the veterinarian José Carlos Magalhães, for support.

\section{References}

ABCCMM. Associação Brasileira dos Criadores do Cavalo Mangalarga Marchador. Padrão da raça. Belo Horizonte: ABCCMangalarga Marchador, 2000. 8p.

ALLEN, W.R.; WILSHER, S.; STEWART, F.; OUSEY, J.; FOWDEN, A. The influence of maternal size on placental, fetal and postnatal growth in the horse. II. Endocrinology of pregnancy. Journal of Endocrinology, v.172, p.237-246, 2002. DOI: https://doi.org/10.1677/joe.0.1720237.

BERBARI NETO, F. Morfometria de campeões e não campeões na raça Campolina. 2009. 105p. Tese (Doutorado) - Universidade Estadual do Norte Fluminense Darcy Ribeiro, Campos dos Goytacazes.

CABRAL, G.C.; ALMEIDA, F.Q. de; QUIRINO, C.R.; PINTO, L.F.B; SANTOS, E.M.; CORASSA, A. Avaliação morfométrica de eqüinos da raça Mangalarga Marchador: medidas lineares. Revista Brasileira de Zootecnia, v.33, p.989-1000, 2004. DOI: https://doi.org/10.1590/S1516-35982004000400019.

CARNEIRO, A.P.S.; MUNIZ, J.A.; CARNEIRO, P.L.S.; MALHADO, C.H.M.; MARTINS FILHO, R.; SILVA, F.F. e. Identidade de modelos não lineares para comparar curvas de crescimento de bovinos da raça Tabapuã. Pesquisa Agropecuária Brasileira, v.49, p.57-62, 2014. DOI: https://doi.org/10.1590/ S0100-204X2014000100008.

CASIUCH, R.L. Origens da raça Mangalarga Marchador. In: CASIUCH, R.L. As costelas do abismo: a história do cavalo real: os mais influentes garanhões do século XX na raça Mangalarga Marchador. São Paulo: Essential Idea, 2016. p.13-35.

FONSECA, M.G.; FERRAZ, G. de C.; LAGE, J.; PEREIRA, G.L.; CURI, R.A. A genome-wide association study reveals differences in the genetic mechanism of control of the two gait patterns of the Brazilian Mangalarga Marchador breed. Journal of Equine Veterinary Science, v.53, p.64-67, 2017. DOI: https://doi.org/10.1016/j.jevs.2016.01.015.

FRADINHO, M.J.; BESSA, R.J.B.; FERREIRA-DIAS, G.; CALDEIRA, R.M. Growth and development of the Lusitano horse managed on grazing systems. Livestock Science, v.186, p.22-28, 2016. DOI: https://doi.org/10.1016/j.livsci.2015.06.006.

FREITAS, A.R. de. Curvas de crescimento na produção animal. Revista Brasileira de Zootecnia, v.34, p.786-795, 2005. DOI: https://doi.org/10.1590/S1516-35982005000300010.

GARCIA, F.P.S.; ALFAYA, H.; LINS, L.A.; HAETINGER, C.; NOGUEIRA, C.E.W. Determinação do crescimento e desenvolvimento de potros puro sangue inglês em Bagé-RS. Revista Portuguesa de Ciências Veterinárias, v.106, p.43-46, 2011.

GONÇALVES, R.W.; COSTA, M.D.; REZENDE, A.S.C.; ROCHA JÚNIOR, V.R.; LEITE, J.R.A. Efeito da endogamia sobre características morfométricas em cavalos da raça Mangalarga Marchador. Arquivo Brasileiro de Medicina Veterinária e Zootecnia, v.64, p.419-426, 2012. DOI: https://doi.org/10.1590/ S0102-09352012000200023. 
HOLMSTRÖM, M.; BACK, W. The effects of conformation. In: BACK, W.; CLAYTON, H. (Ed.). Equine locomotion. $2^{\text {nd }}$ ed. Edinburgh: Saunders Elsevier, 2013. p.229-245.

LAWRENCE, T.L.J.; FOWLER, V.R. Prenatal and postnatal growth. In: LAWRENCE, T.L.J; FOWLER, V.R. Growth of farm animals. $2^{\text {nd }}$ ed. New York: CABI Publishing, 2002. p.193-215. DOI: https://doi.org/10.1079/9780851994840.0193.

MCMANUS, C.M.; LOUVANDINI, H.; CAMPOS, V.A.L. Non linear growth curves for weight and height in four genetic groups of horses. Ciência Animal Brasileira, v.11, p.80-89, 2010. DOI: https://doi.org/10.5216/cab.v11i1.5400.

MISERANI, M.G.; MCMANUS, C.; SANTOS, S.A.; SILVA, J.A. da; MARIANTE, A. da S.; ABREU, U.G.P. de. Avaliação dos fatores que influem nas medidas lineares do cavalo Pantaneiro. Revista Brasileira de Zootecnia, v.31, p.335-341, 2002. Supl. DOI: https://doi.org/10.1590/S1516-35982002000200007.

MOTA, M.D.S. da; OLIVEIRA, H.N. de; PUOLI FILHO, J.N.P. Avaliação do crescimento em potros da raça Quarto de Milha. Revista Electrónica de Veterinaria, v.11, p.1-10, 2010.

PEUGNET, P.; ROBLES, M.; MENDOZA, L.; WIMEL, L.; DUBOIS, C.; DAHIREL, M.; GUILLAUME, D.; CAMOUS, S.; BERTHELOT, V.; TOQUET, M.P.; RICHARD, E.; SANDERSEN, C.; CHAFFAUX, S.; LEJEUNE, J.-P.; TARRADE, A.; SERTEYN, D.; CHAVATTE-PALMER, P. Effects of moderate amounts of barley in late pregnancy on growth, glucose metabolism and osteoarticular status of pre-weaning horses. PLoS ONE, v.10, e0122596 , 2015. DOI: https://doi.org/10.1371/ journal.pone.0122596.

PIMENTEL, A.M.H.; RODRIGUES, W.B.; MARTINS, C.F.; MONTANEZ, N.R.; BOLIGON, A.A.; SOUZA J.R.M. de. Gender on the growth of Criollo foals from birth to three years of age. Ciência Rural, v.47, e20150989, 2017. DOI: https://doi.org/10.1590/0103-8478cr20150989.

R CORE TEAM. R: a language and environment for statistical computing. Vienna: R Foundation for Statistical Computing, 2015. Available at: $<$ http://www.r-project.org $>$. Accessed on: June 122015.

REED, K.R.; DUNN, N.K. Growth and development of the Arabian horse. In: EQUINE NUTRITION AND PHYSIOLOGY SYMPOSIUM, 5., 1977, Saint Louis. Proceedings. Saint Louis: ENPS, 1977. p.76-98.

REZENDE, M.P.G.; SOUZA, J.C. de; MOTA, M.F.; OLIVEIRA, N.M.; JARDIM, R.J.D. Conformação corporal de equinos de diferentes grupos genéticos. Ciência Animal Brasileira, v.17, p.316-326, 2016. DOI: https://doi.org/10.1590/10896891v17i321194.

RIBEIRO, R.A.; SOUZA, F.A.C.; MUNIZ, J.A.; FERNANDES, T.J.; MOURA, R.S. Curva de crescimento em altura na cernelha de equinos da raça Mangalarga Marchador considerandose heterocedasticidade. Arquivo Brasileiro de Medicina Veterinária e Zootecnia, v.70, p.272-278, 2018. DOI: https://doi.org/10.1590/1678-4162-9322.

SANTIAGO, J.M.; REZENDE, A.S.C. de; LANA, Â.M.Q.; FONSECA, M.G.; LAGE, J. Evolution of morphometric measures in the Mangalarga Marchador breed. Revista Caatinga, v.29, p.191-199, 2016. DOI: https://doi.org/10.1590/198321252016v29n122rc.

SANTOS, S.A.; SOUZA, G.S.; ABREU, U.G.P; MCMANUS, C.; COMASTRI FILHO, J.A. Monitoramento do desenvolvimento de cavalos Pantaneiros por meio de curvas de crescimento. Archivos de Zootecnia, v.56, p.647-654, 2007. Supl.1.

SILVA, D.A.S.; PELEGRINI, A.; PETROSKI, E.L.; GAYA, A.C.A. Comparison between the growth of Brazilian children and adolescents and the reference growth charts: data from a Brazilian project. Jornal de Pediatria, v.86, p.115-120, 2010. DOI: https://doi.org/10.2223/JPED.1975.

SOUZA, F.A.C.; FERNANDES, T.J.; MOURA, R.S. de; MEIRELLES, S.L.C.; RIBEIRO, R.A.; CUNHA, F.O.; MUNIZ, J.A. Nonlinear modeling growth body weight of Mangalarga Marchador horses. Ciência Rural, v.47, e20160636, 2017. DOI: https://doi.org/10.1590/0103-8478cr20160636.

SPERANDIO, N.; SANT'ANA, L.F. da R.; FRANCESCHINI, S. do C.C.; PRIORE, S.E. Comparação do estado nutricional infantil com utilização de diferentes curvas de crescimento. Revista de Nutrição, v.24, p.565-574, 2011. DOI: https://doi.org/10.1590/ S1415-52732011000400005.

STAIGER, E.A.; BELLONE, R.R.; SUTTER, N.B.; BROOKS, S.A. Morphological variation in gaited horse breeds. Journal of Equine Veterinary Science, v.43, p.55-65, 2016. DOI: https://doi.org/10.1016/j.jevs.2016.04.096.

TELEKEN, J.T.; GALVÃO, A.C.; ROBAZZA, W. da S. Comparing non-linear mathematical models to describe growth of different animals. Acta Scientiarum. Animal Science, v.39, p.73-81, 2017. DOI: https://doi.org/10.4025/actascianimsci.v39i1.31366.

ZEFERINO, A.M.B.; BARROS FILHO, A.A.; BETTIOL, H.; BARBIERI, M.A. Acompanhamento do crescimento. Jornal de Pediatria, v.79, p.S23-S32, 2003. Supl.1. DOI: https://doi.org/10.1590/S0021-75572003000700004. 